\section{Low-temperature Preservation of Clianthus formosus Pollen}

\author{
H.G. Hughes and C.W. Lee \\ Department of Horticulture, Colorado State University, Fort Collins, \\ CO 80523
}

\section{L.E. Towill}

Agricultural Research Service/U. S. Department of Agriculture National Seed Storage Laboratory, Fort Collins, CO 80523

Additional index words. Sturt's desert pea, in vitro germination, cryopreservation, pollen storage, liquid nitrogen

\begin{abstract}
Pollen from Clianthus formosus (G. Don) Ford and Vickery was tested for viability after desiccation and exposure to low temperatures. Desiccation for 3 hours before freezing at $\mathbf{- 1 8 0 C}$ was sufficient for maintaining pollen germination. Pollen dried for a longer time showed reduced germination when plated directly. However, when pollen was rehydrated by exposure to high humidity before plating, germination was not reduced.
\end{abstract}

Clianthus formosus (Sturt's desert pea) is a native Australian legume that has been cultivated as a garden plant (Wrigley, 1979). The plant has an attractive flower and may have potential for use as a flowering house plant; however, considerable improvement in plant shape and flowering habit is needed. A method for preserving pollen from diverse Clianthus lines for an indefinite period is necessary to overcome problems of space, labor, and cost in maintaining plants that flower at various times. Although storage at 2 to $-20 \mathrm{C}$ increases pollen longevity for many plant species, the use of very low temperatures, such as that of the vapor phase over liquid nitrogen (about $-180 \mathrm{C}$ ), might allow still longer preservation (Roberts, 1975).

Pollen is often classified as either desiccation-tolerant (binucleate pollen grains when shed) or desiccation-sensitive (often trinu-

Received for publication 11 Sept. 1990. This study was supported by Colorado Agricultural Experiment Station Project 604 and USDA/ARS. We thank Melinda Paschal for technical help. The cost of publishing this paper was defrayed in part by the payment of page charges. Under Postal regulations, this paper therefore must be her\&y marked advertisement solely to indicate this fact. cleate or tricellular pollen grains when shed) (Towill, 1985). Desiccation-tolerant pollen usually can survive low temperatures if the pollen is first dried to a relatively low moisture content $(<15 \%$ to $20 \%$ moisture). Since we found no applicable data on low-temperature preservation of pollen from legumes, an investigation with this species was carried out.

Experiments were conducted with pollen from greenhouse-grown Clianthus formosus plants (seed source: M.L. Farrar, East Nowra, N.S.W. Australia). Plants were grown in fiberglass reinforced plastic greenhouses at Colorado State Univ. under natural daylength at a day/night cycle of $23 \pm 3 \mathrm{C} / 20$ and agar. four petri dishes. \pm 3 C. Plants were grown at $\approx 65 \%$ relative humidity $(\mathrm{RH})$ in 1.35 -liter plastic pots containing a mixture of 2 peat : 2 perlite : 1 clay loam soil (by volume). They were irrigated weekly with a nutrient solution containing the following macronutrients (meq/ liter): $3 \mathrm{Ca}^{2+}, 6 \mathrm{~K}^{+}, \mathrm{Mg}^{2+}, 2 \mathrm{NH}_{4}^{+}, 10$ $\mathrm{NO}_{3}, 2 \mathrm{H}_{2} \mathrm{PO}_{4}$, and $2 \mathrm{SO}_{4}^{2-}$; The concentration of micronutrients was the same as that of Hoagland solution (Hoagland and Arnon, 1950).

Pollen was collected in the morning from dehiscing anthers and used within $2 \mathrm{~h}$ for experimentation. In the first experiment, a medium was developed to optimize germination by using the mineral formulation of Brewbaker and Kwack (1963) [mg.liter ${ }^{-1}$ : $500 \mathrm{Ca}\left(\mathrm{NO}_{3}\right) \cdot \mathrm{H}_{2} \mathrm{O}, 200 \mathrm{MgSO}_{4} \cdot 7 \mathrm{H}_{2} \mathrm{O}, 200$ $\mathrm{KNO}_{3}$, and $20 \mathrm{H}_{3} \mathrm{BO}_{3}$ ] and several concentrations of sucrose $(10 \%$ to $30 \%)$ and agar $(0.5 \%$ to $4 \%)$. Pollen was sprinkled over the solidified medium $(60 \times 15-\mathrm{mm}$ petri dishes $)$ and incubated at room temperature for 18 to $24 \mathrm{~h}$. Each of the four replicate petri dishes per treatment was then examined under a dissecting microscope for germination (four fields of vision per replicate). A pollen grain was scored as germinating when the length of the pollen tube exceeded the diameter of the grain. Standard errors of the means within each experiment were computed.

Pollen germination was highest $(46 \%$ to $51 \%$ ) at $10 \%$ sucrose and 0.5 or $1 \%$ agar. Germination decreased considerably at higher agar and sucrose concentrations (Table 1). Since several other species besides Clianthus also were being evaluated (data not shown), a medium was selected that contained $12.5 \%$ sucrose and $1 \%$ agar with the Brewbaker and Kwack minerals. This was used for testing

Table 1. Germination percentages of Clianthus formosus pollen on various concentrations of sucrose

\begin{tabular}{cccccr}
\hline \hline \multirow{2}{*}{$\begin{array}{c}\text { Sucrose } \\
(\%)\end{array}$} & 0.5 & 1 & 2 & 3 & 4 \\
\cline { 2 - 6 } & $46.7 \pm 12^{z}$ & $51.2 \pm 11$ & $29.0 \pm 3$ & $29.0 \pm 2$ & $27.3 \pm 6$ \\
10 & $24.2 \pm 6$ & $31.5 \pm 3$ & $24.0 \pm 4$ & $20.3 \pm 2$ & $17.8 \pm 2$ \\
15 & $20.5 \pm 8$ & $29.0 \pm 4$ & $21.0 \pm 3$ & $17.8 \pm 3$ & $20.8 \pm 2$ \\
20 & $24.0 \pm 8$ & $22.0 \pm 3$ & $19.0 \pm 6$ & $17.0 \pm 2$ & $13.5 \pm 3$ \\
25 & $19.8 \pm 4$ & $16.0 \pm 2$ & $15.0 \pm 3$ & $13.8 \pm 4$ & $4.3 \pm 3$ \\
30 & 4 & 4
\end{tabular}

${ }^{\mathrm{z}}$ Values $( \pm \mathrm{SE}$ ) for each treatment combination are the average germination counts from four fields for 
Table 2. Germination percentages of Clianthus formosus pollen as affected by duration of desiccation.

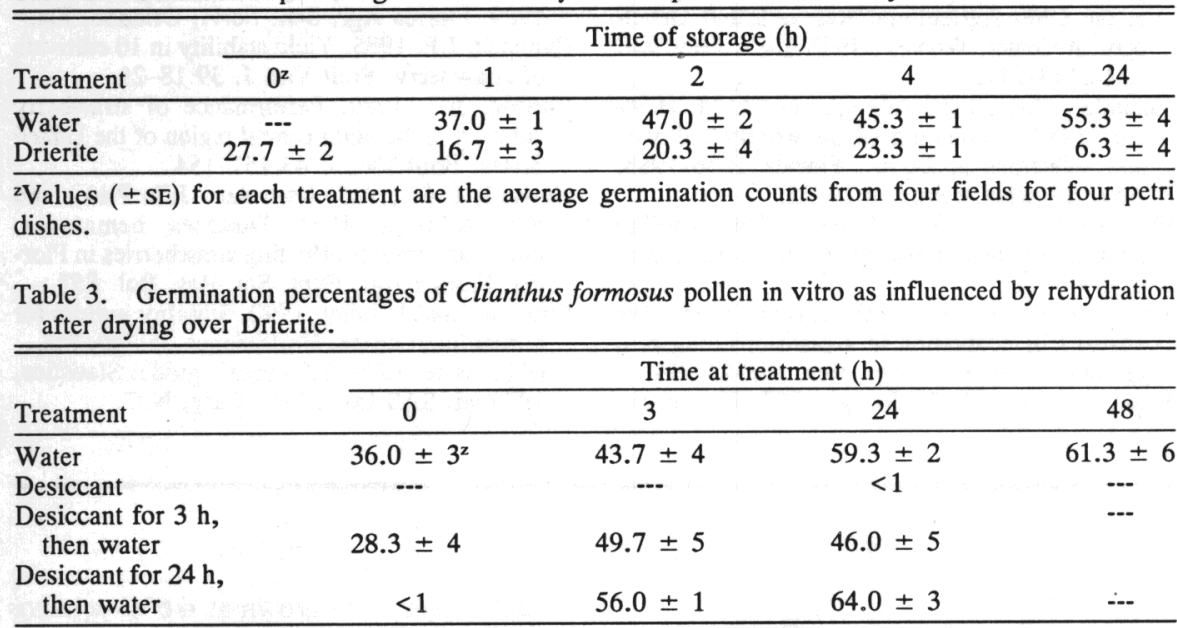

${ }^{\mathrm{z}}$ Values $( \pm \mathrm{SE})$ for each treatment are the average germination counts from four fields for four petr dishes.

Table 4. Effect of low-temperature storage on in vitro germination of Clinthus formosus pollen.

\begin{tabular}{|c|c|}
\hline Treatment $^{z}$ & $\begin{array}{c}\text { Germination } \\
(\%)\end{array}$ \\
\hline Freshly collected, direct plate & $57.0 \pm 3 \mathrm{a}^{y}$ \\
\hline $3 \mathrm{~h}$ over desiccant, direct plate & $21.7 \pm 3 b$ \\
\hline $\begin{array}{l}3 \mathrm{~h} \text { over desiccant, } 19 \mathrm{~h} \text { at } \\
-180 \mathrm{C} \text {, direct plate }\end{array}$ & $18.0 \pm 7 b$ \\
\hline $\begin{array}{l}3 \mathrm{~h} \text { over desiccant, } 19 \mathrm{~h} \text { at } \\
-180 \mathrm{C}, 3 \mathrm{~h} \text { rehydration }\end{array}$ & $56.0 \pm 5 a$ \\
\hline $\begin{array}{l}22 \mathrm{~h} \text { over desiccant, direct plate } \\
22 \mathrm{~h} \text { over desiccant, } 2 \text { days }\end{array}$ & $5.0 \pm 2 \mathrm{c}$ \\
\hline $\begin{array}{l}-180 \mathrm{C} \text {, direct plate } \\
22 \mathrm{~h} \text { over desiccant, } 2 \text { days }\end{array}$ & $20.3 \pm 4 b$ \\
\hline$-180 \mathrm{C}, 3 \mathrm{~h}$ rehydration & $62.7 \pm 4 \mathrm{a}$ \\
\hline
\end{tabular}

${ }^{2}$ Values $( \pm \mathrm{SE})$ for each treatment are the average germination counts from four fields for four petri dishes.

'Mean separation at $P=0.05$ by LSD. Arcsin transformation of data was used although nontransformed averages are shown here.

germination in subsequent drying and lowtemperature experiments.

We determined whether $C$. formosus pollen is sensitive to desiccation and rehydration. Small amounts of freshly collected pollen were placed in small test tubes and inserted in beakers containing either a desiccant (Drierite or $\mathrm{CaCl}_{2}$ ) or water, and then were incubated at room temperature for up to 24 $\mathrm{h}$ before being tested for germination. This and subsequent experiments consisted of three replicates (petri dishes) per treatment, with four nonoverlapping fields of vision examined per replicate. Because of the small amounts of pollen obtained, the pollen moisture contents were not measured. Pollen stored over a desiccant for 1,2 , or $4 \mathrm{~h}$ had similar germination as fresh pollen, but by $24 \mathrm{~h}$, germination had been reduced to about one- fourth of the control (Table 2). Pollen storage over water for as little as $1 \mathrm{~h}$ increased germination over that plated without rehydration. In many species with desiccationtolerant pollen, a period of rehydration (30 $\min$ to $24 \mathrm{~h}$ at $100 \% \mathrm{RH}$ ) is necessary after drying to obtain maximum in vitro germination (Towill, 1985).

Humidification of $C$. formosus pollen after desiccation but before germination was tested resulted in a substantial increase in germination (Table 3). Two points are noteworthy. Pollen stored as long as $48 \mathrm{~h}$ at room temperature and $\approx 100 \% \mathrm{RH}$ still retained a high percentage of germination. Pollen dried 24 $\mathrm{h}$ over a desiccant also retained a high germination percentage when it was rehydrated ( 3 or $24 \mathrm{~h}$ at $100 \% \mathrm{RH}$ ) before plating. Thus, the capacity for germination of $C$. formosus pollen was not lost at room temperature even in the hydrated state. Since germination after desiccation and rehydration is retained, pollen handling times for this species are not critical for maintaining viability for use in crossing and in short-distance transportation.

The ability to tolerate desiccation and rehydration suggested that this pollen might survive low temperatures. Dehydrated pollen was placed in the vapors above liquid nitrogen within a liquid nitrogen refrigerator (about $-180 \mathrm{C}$ ) for several hours, and then thawed in 40C water (thermocouple measurements of warming rate were $\approx 2000 \mathrm{C} / \mathrm{min}$ ). Pollen thus treated retained a high percentage of germination when the pollen was rehydrated ( $3 \mathrm{~h}$ at $100 \% \mathrm{RH})$ before plating (Table 4$)$. Although the amount of pollen collected was too little to accurately determine moisture content, $3 \mathrm{~h}$ over the desiccant was sufficient to allow pollen to survive exposure to about $-180 \mathrm{C}$. Three hours of rehydration were sufficient to give $56 \%$ to $63 \%$ germination. Pollinations were made with both control and low temperature-treated pollen. Seed set occurred with both treatments; however, no quantitative studies were performed.

Pollen that was hydrated by exposure to $100 \% \mathrm{RH}$ and then exposed to $-180 \mathrm{C}$ failed to germinate. Freshly collected pollen that was not given a drying treatment gave variable percent germinations after direct exposure to $-180 \mathrm{C}$, probably because of variable pollen moisture contents at collection time.

The effect of warming rates ranging from moderately slow (air thawed at 22C: $\approx 100 \mathrm{C} / \mathrm{min}$ in the sample tube) to fast (immersion of tube with pollen into 40C water: $\approx 2000 \mathrm{C} / \mathrm{min}$ ) did not affect viability of dried pollen exposed to liquid nitrogen vapor (germination $54 \%$ to $74 \%$ ). Repeated cooling and warming of pollen for three cycles did not greatly affect viability (data not shown). Both observations were consistent with the suggestion that pollen moisture had been reduced such that intracellular ice did not form with the fast-cooling technique. From a practical view, these observations suggest that a pollen vial can be repeatedly sampled and that minor variations in thaw procedure would not decrease viability.

Thus, as with other desiccation-tolerant pollen, drying of pollen over a desiccant for 3 to $22 \mathrm{~h}$ followed by exposure to low temperatures maintained high survival percentages. Samples were stored for up to 11 days at $-180 \mathrm{C}$ with no decrease in viability. Use of this low-temperature methodology should allow storage of pollen for at least a few years as noted in other species treated similarly (Towill, 1985), and should increase efficiency in using resources for breeding Clianthus formosus.

\section{Literature Cited}

Brewbaker, J.L. and B. Kwack. 1963. The essential role of calcium ion in pollen germination and pollen tube growth. Amer. J. Bot. 50:859865 .

Hoagland, D.R. and D.I. Arnon. 1950. The waterculture method for growing plants without soil. Calif. Agr. Expt. Circ. 347, Univ. of California-Davis.

Roberts, E.H. 1975. Problems of long term storage of seed and pollen for genetic resources conservation. Crop genetic resources for today and tomorrow. Cambridge: Cambridge Univ. p. 269-296

Towill, L.E. 1985. Low temperature and freeze-/ vacuum-drying preservation of pollen, p. 171198. In: K.K. Kartha (ed.). Cryopreservation of plant cells and organs. CRC, Boca Raton, Fla.

Wrigley, J.W. 1979. Australian native plants. Collins, Sydney. p. 103-104. 